\title{
Romanian Universities in Social Media. An Analysis Based on International Rankings
}

\author{
Dumitrache Bogdan Bratoveanu ${ }^{1}$, Adrian Petre Liptac, Roxana Sârbu ${ }^{3}$ and Silvius \\ Stanciu $^{4}$ \\ 1224) "Dunărea de Jos" University of Galați, Galați, Romania. \\ 3) The Bucharest University of Economic Studies, Bucharest, Romania. \\ E-mail: bbratoveanu@ugal.ro; E-mail: adrianliptac@yahoo.com \\ E-mail: sarbu.roxana@ase.ro, E-mail: sstanciu@ugal.ro
}

\begin{abstract}
Please cite this paper as:
Bratoaveanu, D.B, Liptac, A.P., Sîrbu, R, and Stanciu, S., 2021. Romanian Universities in Social Media. An Analysis Based on International Rankings.

In: R. Pamfilie, V. Dinu, L. Tăchiciu, D. Pleșea, C. Vasiliu eds. 2021.

7th BASIQ International Conference on New Trends in Sustainable Business

and Consumption. Foggia, Italy, 3-5 June 2021. Bucharest: ASE, pp. 930-938

DOI : $10.24818 / B A S I Q / 2021 / 07 / 116$
\end{abstract}

\begin{abstract}
Social networks can offer users considerable benefits in terms of information, communication and connections, educational opportunities and promotion of universities, various educational programs and systems. The conditions of social distancing imposed by the COVID-19 Pandemic increased the importance of social media networks. Universities, including those situated in Romania, have perceived the potential of the Internet use and online promotion, including social networks. The research proposes an analysis of the presence of Romanian universities on the main social networks, using the information provided by social networks and international rankings of universities. For documentation, the authors used uniRank ${ }^{\mathrm{TM}}$, Facebook, Twitter, LinkedIn, Instagram, YouTube, scientific databases. Data processing was performed using spreadsheet systems. The study showed that the public universities in Romania are better represented on social networks compared to the private ones, that there is a gap between the preferences of social network users and those of academic institutions, as well as differences in approach to social networks from local universities. Facebook, LinkedIn and YouTube are the networks the most frequently used by Romanian universities, and Instagram is at the opposite pole. The research conducted can be useful for higher education institutions in Romania, which can align to the international trends in the use of social media in order to promote the image, recruit students or develop educational programs.
\end{abstract}

Keywords: Social Media, Universities, Facebook, Twitter, LinkedIn, Instagram, YouTube, Romania. DOI: $10.24818 / B A S I Q / 2021 / 07 / 116$

\section{Introduction}

Social media networks allow users to introduce themselves, join interest groups and establish or maintain connections with other people, being increasingly present in the promotion of companies and public institutions (Iordache, 2014). These networks can focus on professional issues (e.g. LinkedIn.com), connecting users with common interests, or university students (Facebook.com).

Restrictions due to the COVID-19 Pandemic have led to an increasing importance of the Internet, both for productive activities and for marketing activities.

Universities are no exception trend, a high number of academic institutions being more and more active on social networks. Facebook, Twitter, Linkedin, Instagram, YouTube are increasingly used for the 
transmission of educational information, for the promotion of higher education institutions and for the recruitment of new students.

\section{Materials and methods}

Clarivate Analytics, SCOPUS, Google Scholar and ResearchGate databases were used for bibliographic documentation. For specialized information, the social networks Facebook, Twitter, Instagram, Linkedin YouTube were used.

Data on the presence of academic institutions in social media were selected from the uniRank Ranking TM, which includes over 13,800 officially recognized universities and colleges in 200 countries. The data collected were processed, graphically plotted and interpreted. The results obtained were compared with other information from the literature.

\section{Results}

The study conducted by Alwreikat, Abu Zaid and Shehata (2021) showed that there is an important correlation between the use of Facebook and the collaborative learning, which means that students get better academic performance if they spend more time on Facebook. Furthermore, the study found that Facebook's use of collaborative learning varies between social sciences and scientific subjects. Social networks such as Facebook have become popular tools in marketing practice for various organizations, including libraries. To build relationships with library users, libraries hope that social networks can actively involve user communities with their collections, services, and activities (Cheng, Lam and Chiu, 2020).

In recent years, social networks have provided higher education institutions with modern means of communication with target groups. In the study by Eger et al. (2020), the research was conducted on top public universities in four Central European countries, with a focus on their public relations activities on Facebook. The aim of the research was to evaluate the use of Facebook by selected universities and to provide a set of practical guidelines on successful communication with the public. The study's findings provided evidence of increased use of Facebook by universities in public relations. Moreover, research results revealed that different post features generate different customer behaviour. The study contributed to a better understanding of social media marketing activities in the field of higher education.

Stanciu, Sârbu and Bucur (2017), in an analysis of the Romanian education system, show that local universities, and especially those financed from the public budget, are open to innovation, being able to adopt the most modern teaching and communication methods, including the Internet. Social networks in higher education have become an essential chapter in almost all institutions.

According to Sehl's research, 98\% of universities use social media on campus (Sehl, 2020). Covid-19 has moved higher education entirely online, and universities need to continuously adapt to these developments. One area that quickly adapted to the new conditions was the recruitment of students, and social networks played an important role in these activities.

The Singular study, quoted by The Time Higher Education (2021) showed that $73 \%$ of marketing leaders have increased their marketing efforts during this period. The study found that it reallocates $28 \%$ to more online advertising, $18 \%$ to more content marketing, $15 \%$ to organic growth and $12 \%$ to social media marketing. While e-mail is a great way to communicate important information, social media is the environment where students like to "get entertained" and spend a lot of time.

Instagram is a way for universities to interact with potential students, share stories about graduates, and provide valuable advice. The administrators of the University of Queensland's Instagram account send home study tips, showing that they are in touch and empathetic with what their students are going through. Indiana University is redistributing videos from students' time at home, and a clip of a violin student garnered more than 19,000 views.

These examples show that social networks can become an important way of communication and promotion for the universities. 


\section{Universities on Facebook}

The uniRank ranking provides important information about the use of the Facebook social platform (FB) among higher education institutions. Internationally, uniRank is the only ranking that offers a vast list of universities and colleges with an official presence on FB.

The list is arranged alphabetically by country name and then ranked by total number of likes / fans. FB rankings are published twice a year, in February and August.

The hierarchy of universities' presence on FB, made by uniRank (2021), shows that over 10,000 universities, representing about $73 \%$ of the almost 14,000 universities analyzed are present on this social network at the beginning of 2021. Between August 2018 and February 2021, about 700 universities have created a page on FB (figure 1).

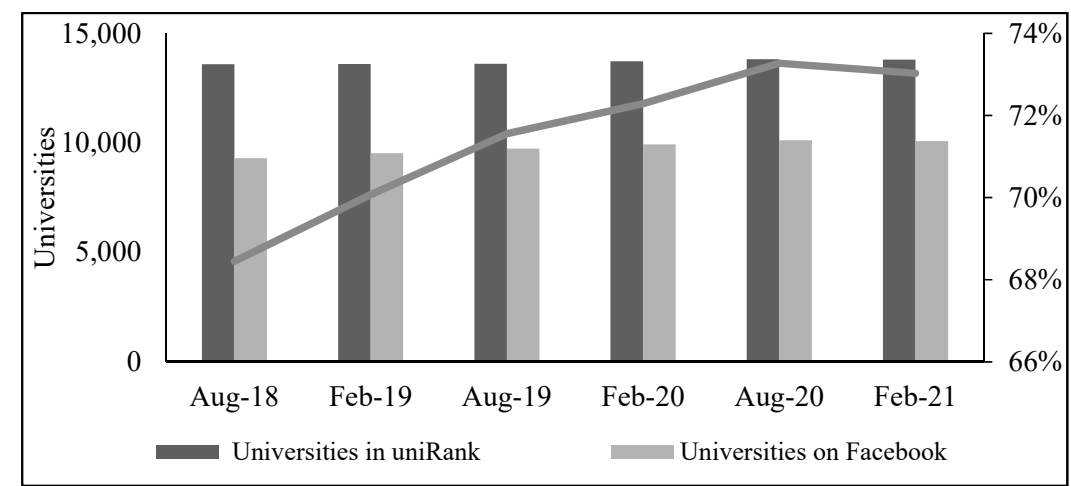

Figure no. 1. Universities on Facebook (2018-2021) Source: Authors, by using uniRank, 2021

More than 40,000 visitors daily appreciate the FB pages of universities in the uniRank rankings, which also present an international top of higher education institutions according to the number of fans (figure $2)$. The most popular universities on FB internationally, by number of fans / likes are Harvard, USA $(6,148,338)$, University of Oxford, United Kingdom $(4,267,046)$ and Universidad Nacional Autónoma de México, Mexico $(3,276,284)$.

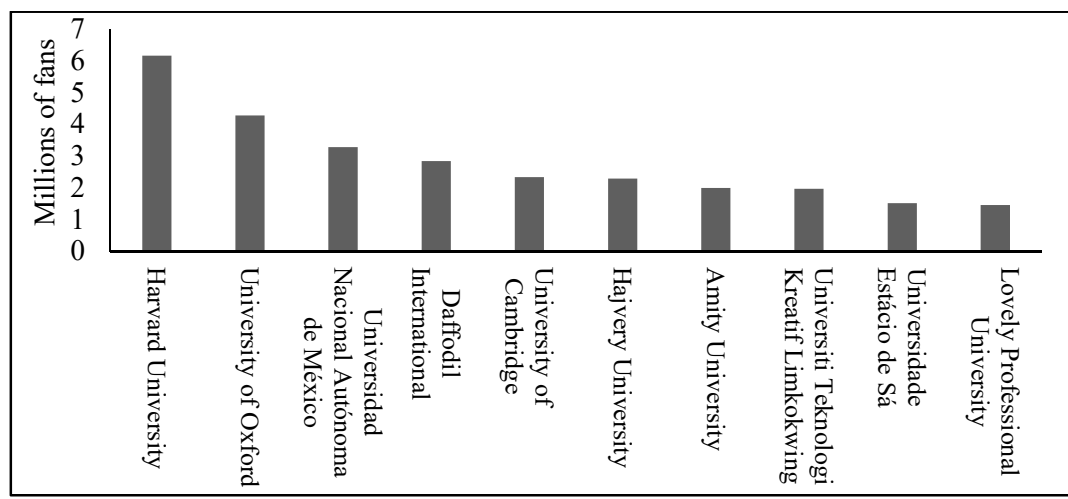

Figure no. 2. Top 10 International - Universities by Facebook page (2021)

Source: Authors, by using uniRank, 2021

Of the 85 functional civilian universities in Romania (according to the data of the National Institute of Statistics, 2021), 67 institutions have created FB pages, which add up to the appreciations of 1,130,346 likes / fans. 34 of them are public institutions, which cumulates a total of 814,357 likes, with an average of 23,267 likes / institution. Compared to state universities, the 33 private universities had, in February 2021, about 315,989 followers and a much lower institutional average of 9,874 likes / institution. Only 
one private university, Spiru Haret University of Bucharest, was included in the Top 10 FB in Romania (figure 3).

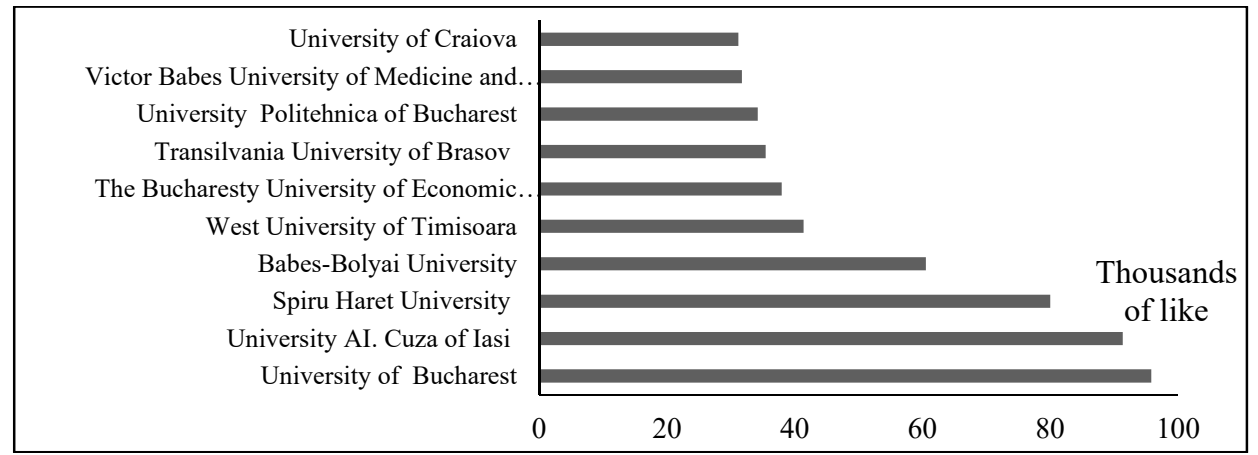

Figure no. 3. Top Romanian Universities on Facebook Source: Authors, by using uniRank, 2021

With 21,473 likes, "Dunărea de Jos” University ranks 19th in Top Romania FB universities pages.

\section{Universities on Twitter}

8,150 out of a total of 13,798 higher education institutions included in the uniRank database had adopted an official Twitter page by February 2021. The presence of universities on Twitter recorded a continuous increase between August 2018 and February 2021, reaching a number of 8,150 institutions, out of the 13,789 registered and an increase of their share by more than $4 \%$ (figure 4 ).

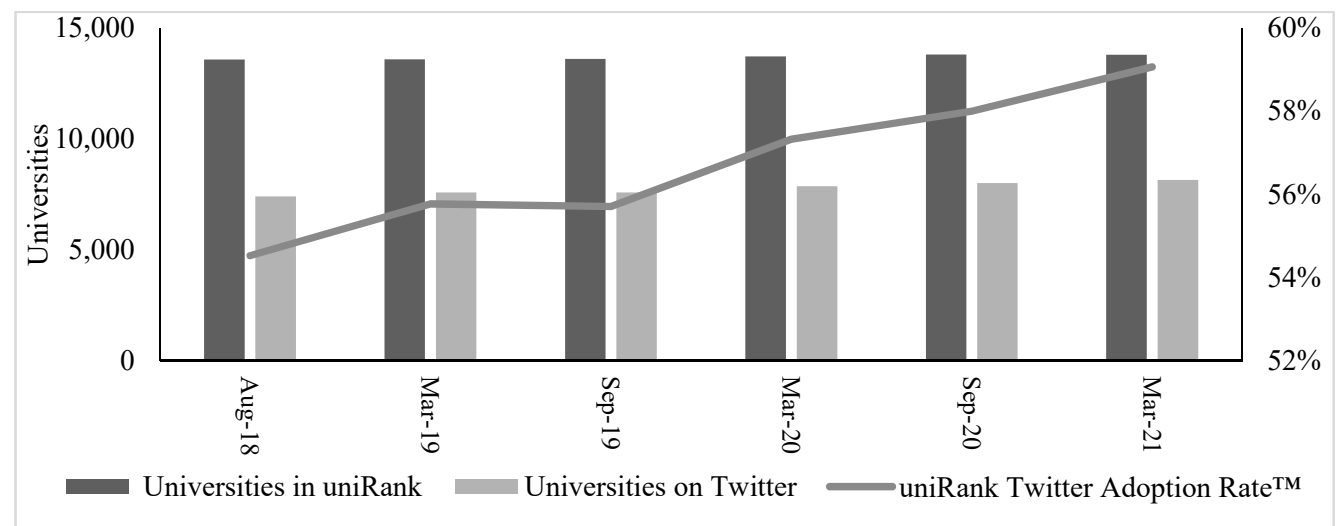

Figure no. 4. Universities on Twitter (2018-2021)

Source: Authors, by using uniRank, 2021

A lot of factors can influence the visibility of universities' Twitter pages, such as the reputation and size of the university, the online presence, the level of Internet use and the speed of the connection, etc. Some large universities have adopted several Twitter pages, associated, for example, with each faculty and / or each administrative area. uniRank 2021 uses the most general institutional Twitter page for each university evaluated.

32 Romanian universities are present on Twitter, totaling 14,428 followers, the first position being occupied by Spiru Haret University, with 4,464 followers (figure 5). 


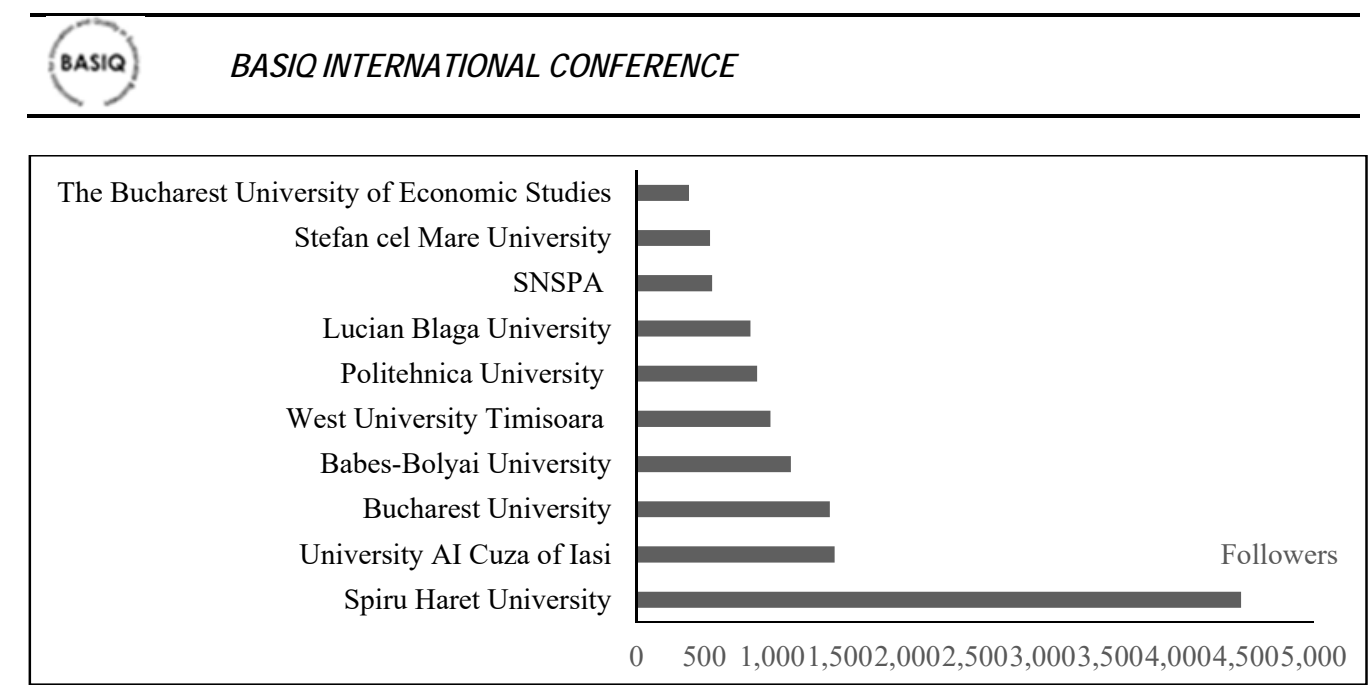

Figure no. 5. Top 10 Romanian Universities on Twitter Source: Authors, by using uniRank, 2021

Of the 32 universities with a Twitter page, the 20 public institutions have 9,113 followers, with an average of 480 followers, while private universities are followed by 5,315 people, at an average of 409 followers / institution. The Twitter page of "Dunărea de Jos" University of Galati has 77 followers and ranks $18^{\text {th }}$ in Top Twitter Romania.

\section{University on LinkedIn}

62 universities in Romania, of which 35 public and 27 private, have at least one LinkedIn page (figure 6). Their distribution by counties / cities of Romania is presented in figure 6. Bucharest, with 20 universities, is on the first position, Iași and Timişoara, with 6 universities each, occupy the following positions. Galați is present in the uniRank statistics (2021) with the "Dunărea de Jos" University of Galați and with the Danubius University.



Figure no. 6. Romanian universities using LinkedIn, by county Source: Authors, by using uniRank, 2021

\section{Universities on Instagram}

Like other rankings based on social networks, Instagram uniRank (2021) proposes a ranking of each university based on the total number of followers, without considering an assessment of the quality of education or the level of academic services provided. Of the 13,813 universities in the uniRank database, almost $49 \%$ have an Instagram account (figure 7 ). 


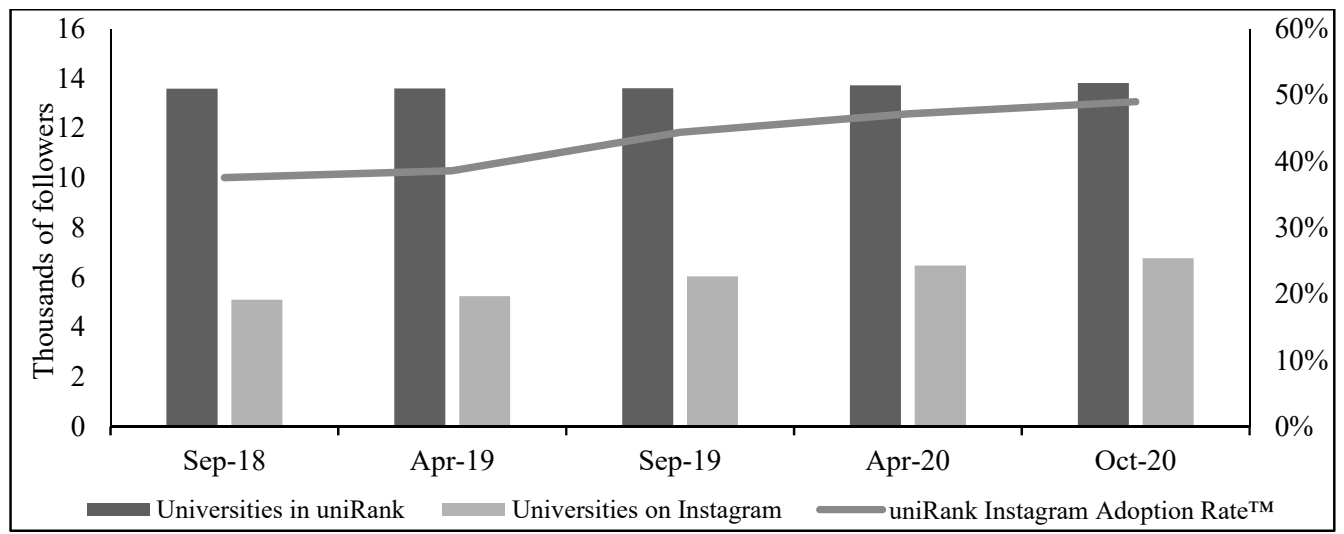

Figure no. 7. Universities on Instragram (2018-2021)

Source: Authors, by using uniRank, 2021

19 Romanian universities are present on Instagram and have a total of 4,256 posts and 36,658 likes. Of these, the 16 public universities had a total of 3,032 posts, being followed by 33,518 people, with an average of 11 people / post. With 1,315 followers and 340 posts, the "Dunărea de Jos" University of Galați occupied in 2021 the 8th position in the national ranking, with an average of 4 followers per post (figure 8).

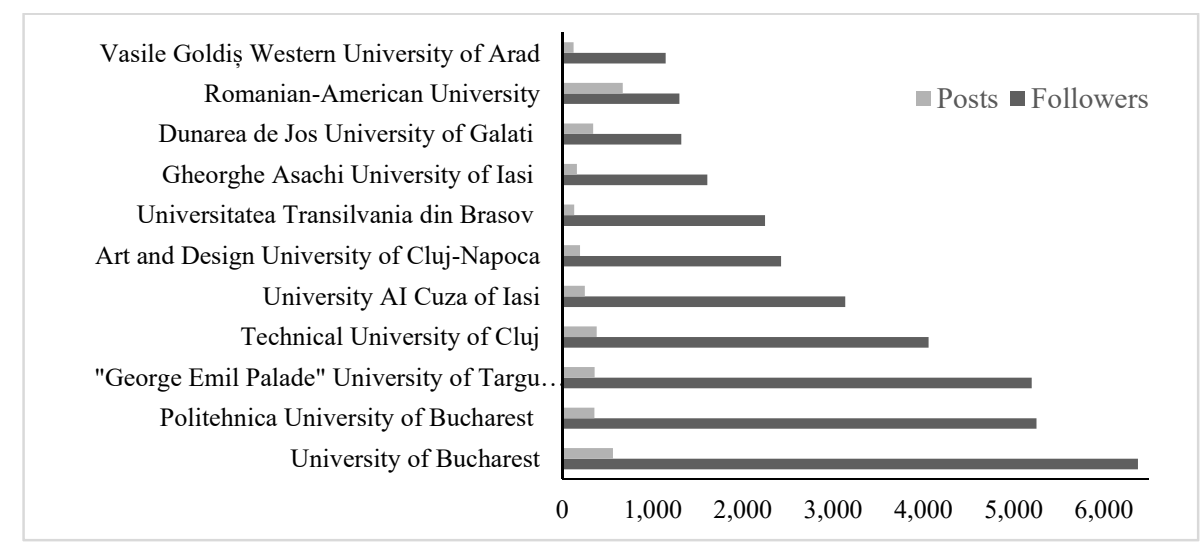

Figure no. 8. Top 10 Romanian Universities on Instagram Source: Authors, by using uniRank, 2021

\section{Universities in YouTube}

There are 8,381 out of a total of 13,723 higher education institutions included in the uniRank database that have adopted an official institutional YouTube page. The estimated number of universities adopting a YouTube page has been calculated by identifying institutional YouTube pages through two methods: direct submission from Universities, or a search of YouTube channel links publicly published in the Universities' homepages (figure 9). 



Figure no.9. Universities on YouTube (2018-2021)

Source: Authors, by using uniRank, 2021

46 universities in Romania have created YouTube channels, where 15,199 materials have been uploaded, with an average of 330 posts / university. With 1,520 posts, University A.I Cuza University of Iasi ranks first (figure 10), and at the opposite pole we find the the Danubius University of Galați, with zero posts. "Dunărea de Jos" University of Galați occupies the 37th position in the national ranking, with 19 posts.

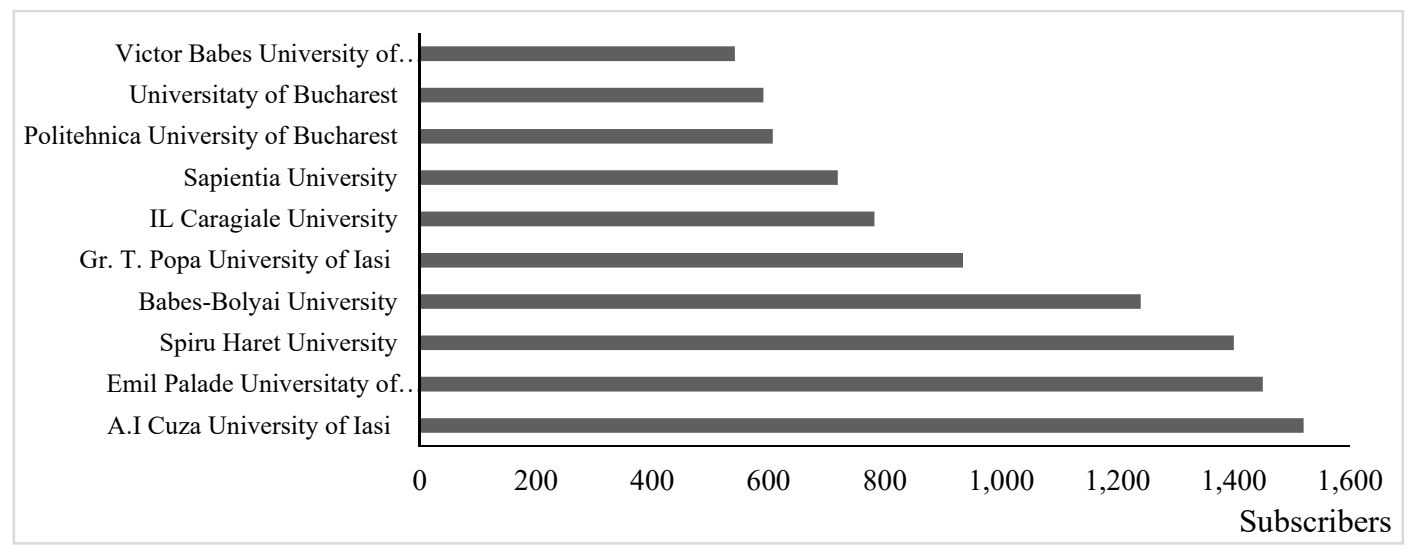

Figure no. 10. Top 10 Romanian Universities on YouTube

Source: Authors, by using uniRank, 2021

With 11,632 posts, the 33 state universities in Romania cover about $76.53 \%$ of the total posts on Youtube of all Romanian educational institutions. The Romanian universities show a different degree of attraction compared to social networks. A total of 226 pages / channels are opened by the Romanian institutions on the 5 analysed networks.

Facebook, LinkedIn and YouTube occupy the first positions in the preferences of higher education institutions in our country, while Instagram is on the last position, with only 19 pages opened by universities (figure 11). 


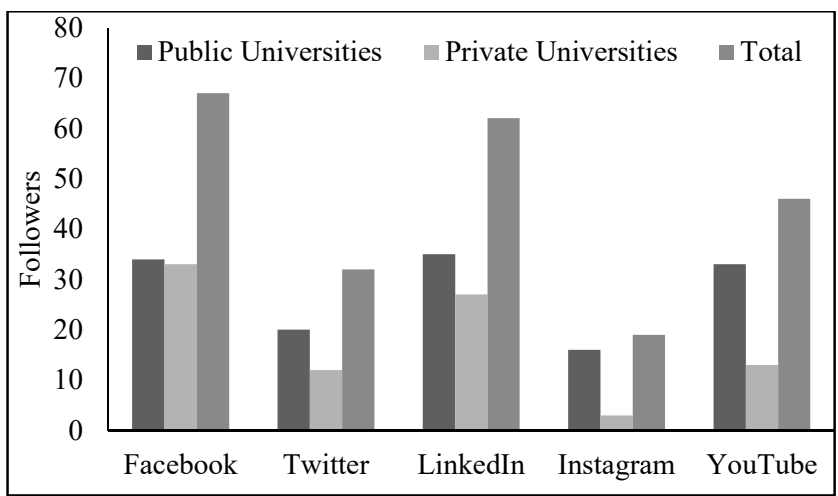

Figure no. 11. Universities in Romania on the main social networks

Source: Authors, by using uniRank, 2021

Although private universities are more flexible and can manage funds more easily, their presence on social networks is lower than publicly funded institutions.

According to the Annual Digital Report worldwide and manafu.ro, quoted by AdSociety (2021), the top of social networks in Romania according to the number of monthly users is dominated by Facebook (12,040,000; source: Napoleoncat) and Youtube (12,000,000; source: Youtube Romania), followed by TikTok (5,364,860; source: TikTok), Instagram (5,053,000; source: Napoleoncat), LinkedIn (3,014,000; source: Napoleoncat), Snapchat (2,354,700; source: Datareportal), Pinterest (1,309,000; source: Datareportal), Twitter: 668,000; source: Datareportal). Romanians give the highest number of likes on Facebook, 18 times a month on the average, while the global average is 11 likes.

\section{Conclusions}

A high number of Romanian universities have aligned to the international trend in transmitting educational information and promoting their image by using social networks. The study was based mainly on the information provided by the international university ranking system uniRank, 2021 edition. A share of universities between $22 \%$ and $78 \%$ of all accredited educational institutions has opened at least one promotion page on a social network. About $80 \%$ of local universities are present on FB, $70 \%$ on LinkedIn and about $50 \%$ on YouTube, the least used Instagram, where we find less than $20 \%$ of universities. There is a gap between the presence of local universities on social networks and the preferences of Romanian consumers for socialization services. Romanian institutions should assess in advance the impact of paid promotions on social networks, in order to address the targeted consumer segment and to obtain the best results.

\section{Aknowledgements}

This work is supported by the project ANTREPRENORDOC, in the framework of Human Resources Development Operational Programme 2014-2020, financed from the European Social Fund under the contract number 36355/23.05.2019HRD OP /380/6/13 -SMIS Code: 123847.

\section{References}

Abrevieri.ro, 2021. Indicatives of the counties in Romania, [online] Available at: $<$ http://abrevierile.ro/colectii/indicative-judete-romania $>$ [Accessed 10 April 2021].

AdSociety, 2021. The most used social network in Romania (2020), [online] Available at: $<$ https://www.doads.ro/cele-mai-utilizate-retele-sociale-in-romania-2020> [Accessed 04 April 2021].

Alwreikat, A., Abu Zaid, M.K. and Shehata, A., 2021. Determinants of Facebook use among students and its impact on collaborative learning. Information Development, Article Number: 02666669211005819 . 


\section{BASIQ INTERNATIONAL CONFERENCE}

Cheng, W.W.H., Lam, E.T.H. and Chiu, D.K.W., 2020. Social media as a platform in academic library marketing: A comparative study. Journal of Academic Librarianship, 46(5), Article Number: 102188.

Eger, L., Egerová, D., Tomczyk, L., Krystoň, M. and Czeglédi, C., 2020. Facebook for Public Relations in the higher education field: a study from four countries Czechia, Slovakia, Poland and Hungary. Journal of Marketing for Higher Education, pp.1-21. https://doi.org/10.1080/08841241.2020.1781737.

Institutul Naţional de Statistică, 2021. TempoOnline, Universities, [online] Available at: $<$ http://statistici.insse.ro:8077/tempo-online/\#/pages/tables/insse-table> [Accessed 04 April 2021].

Iordache, D.D., 2014. Utilizarea reţelelor de socializare în rândul studenţilor români - variabile, avantaje şi limite. Revista Română de Interacţiune Om-Calculator, 7(3), pp.195-208.

Onete, C.B., Dina, R. and Vlad, D.E., 2013. Social Media in the Development of Sustainable Business. Amfiteatru Economic, 15(7), pp.659-670.

Sehl, K., 2020. Social Media in Higher Education: 8 Essential Tips, [blog] Available at: $<$ https://blog.hootsuite.com/social-media-in-higher-education> [Accessed 02 April 2021].

Stanciu, S., Sârbu, R. and Bucur, R.C., 2017. An analysis of the Romanian market of higher education. In Proceedings of BASIQ 2017 International Conference on New Trends in Sustainable Business and Consumption. Graz, Austria, May 31-June 3, 2017, pp.624-632.

Times Higher Education, 2021. Digital student recruitment in the time of coronavirus, [online] Available at: $<$ https://www.timeshighereducation.com/hub/keystone-academic-solutions/p/digitalstudent-recruitment-time-coronavirus $>$ [Accessed 02 April 2021].

uniRank $^{\mathrm{TM}}$, 2021. Universities in Europe, Higher Education in Europe, [online] Available at: $<$ https://www.4icu.org $>$ [Accessed 04 April 2021]. 